\title{
A Closer Look at the Eric Garner Incident: The New York Police Department Should Review Its Policy Instead of Trying Its Police Officer
}

Journal of Criminal Justice and Law: Official Journal of the Law and Public Policy Section of the Academy of Criminal Justice Sciences Volume 2, Issue 2, pp. 122-135 (2018)

\section{Andrew J. Costello '}

\begin{abstract}
After an examination of the death of Eric Garner, existing laws and current practices of the New York Police Department (NYPD) come into question. A step-by-step breakdown of the events after the death of Eric Garner explains the outcome of legal decisions of the criminal process against Police Officer Pantaleo made by the Richmond County District Attorney's Office and the U.S. Attorney's Office. An explanation and the likely outcome of the NYPD's upcoming administrative trial are presented from an insider's point of view. The author argues that the likely conviction of Officer Pantaleo on administrative charges, resulting in his termination, will not produce its intended effect and may be counterproductive in the effort to prevent future deaths of persons in police custody. Suggestions to change NYPD enforcement policy and training, in addition to current New York State law involving access to Grand Jury transcripts and evidence, are presented.
\end{abstract}

\section{Keywords}

Police, use of force, death in custody, NYPD, QOL, asphyxia

The death of Eric Garner raised several concerns regarding law enforcement policies and training issues within the New York City Police Department (NYPD) and how police officers are tried for criminal and administrative matters. From the first appearance of the arrest video taken with a bystander's cell phone, a large portion of the public was taken aback at what appeared to be a "chokehold" applied to a suspect and a lack of medical care provided by either the NYPD or Emergency Medical System (EMS) technicians. Several people

\footnotetext{
'Department of Behavioral Sciences, New York Institute of Technology, Old Westbury, New York, USA
}

Corresponding Author:

Andrew J. Costello, Assistant Professor, New York Institute of Technology, Old Westbury, New York, 11568, USA; E-mail: acoste01@nyit.edu 
were perplexed when the officers were not indicted by a Grand Jury in Richmond County and when the U.S. Attorney's Office did not follow up regarding civil rights violations. The author will go through the Eric Garner incident from start to finish and explain how and why most of the outcomes occurred, provide some insight into the pending administrative trial, and make a case for filing neither civil rights violations nor internal administrative charges against Police Officer Daniel Pantaleo. The author ${ }^{1}$ will argue that instead of allocating resources to the administrative prosecution of Police Officer Pantaleo, the NYPD should direct its efforts to reviewing its existing policy and recommending changes in state legislation related to the access to transcripts of Grand Jury testimony and evidence.

\section{An Analysis of the Eric Garner Incident}

Eric Garner was arrested for selling untaxed cigarettes on a sidewalk in the Tompkinsville area of Staten Island on July 17, 2014. For some reason, unlike during previous encounters with the NYPD, on this day Eric Garner decided to make a stand and resist arrest. Officer Daniel Pantaleo was one of the many arresting officers who subdued Eric Garner, a large, 6 ft 2 in, 350-lb male (Murray, Marcius, \& Parascandola, 2014). According to emergency medical technicians (EMTs) and police at the scene, Eric Garner was breathing when it was decided to transport him to Richmond University Medical Center (Baker, Goodman, \& Meuller, 2015). During transport, he went into cardiac arrest. Doctors at the hospital emergency department administered cardiopulmonary resuscitation (CPR), but Eric Garner died at 4:34 p.m. in the hospital (Associated Press, 2016). Although several excerpts of the report were released, the Medical Examiner's report in its entirety was never fully released. The manner of death was homicide. The cause of death was never fully reported, and it is still unclear if his death was related to the "chokehold" (Goldstein \& Schweber, 2014). Needless to say, the untimely death of any person is tragic.

To determine criminality and violation of department rules, the reason for the NYPD enforcement of the law against selling untaxed cigarettes must be explored. In addition, the specific reason why Eric Garner was a particular subject for the enforcement action should be explained. First, the NYPD has enforced the law against the sale of untaxed cigarettes at a precinct level since 1996. The practice was considered to be a Quality of

\footnotetext{
${ }^{1}$ Andrew J. Costello retired from the NYPD after a 26-year career and has the utmost respect for the department as the premiere law enforcement agency in the world. He greatly admires Police Commissioner O'Neill and has worked with and for him during his career in the NYPD. The author rose through the ranks from Police Officer through Deputy Inspector and has administered most parts of the NYPD disciplinary process, including issuing command disciplines, suspending police officers, and even assisting in their termination and imprisonment. Command disciplines are low-level informal disciplinary sanctions resulting in up to the loss of 10 days of accrued vacation time. Modification of an officer's duty status involves the removal of firearms and assignment to administrative duties while the officer is still receiving pay. When an officer is suspended from service, firearms are removed and the officer does not receive pay. Termination and imprisonment are selfexplanatory. The author fully understands the need for disciplining and convicting police officers of crimes and has done so. He understands that the NYPD, like other institutions, has problems and is not its apologist.
} 
Life (QOL) issue initially, involving the use of brick and mortar storefronts to conceal the sale of illegal drugs, and was considered a nuisance under the abatement laws of the City of New York. In addition, the existence of these storefronts denied tax revenue to the state as well as the control of cigarette sales. If three incidents at a particular storefront were considered to be a nuisance ${ }^{2}$ within a 6-month period, the NYPD Legal Bureau obtained a temporary court order to shut the storefront down. The storefront was secured by padlock, and the owners appeared in court to reopen their business, usually within 3 days. In most cases, the reopening was a negotiated settlement between the NYPD Legal Bureau and the owners (see NYPD Patrol Guide 214-01 "Padlock Law" Program). It should be remembered that although these abatement actions were initiated by an offense under New York State (NYS) Tax Law or NYS Penal Law, they were civil proceedings.

A typical nuisance abatement enforcement action performed by the NYPD is overseen by a supervisor of the rank of Sergeant or Lieutenant, who directs an undercover police officer to purchase a loose cigarette, a package of cigarettes without a NYS tax stamp, or marijuana. If the complaint is about the sale of alcohol to a person younger than 21 years of age (the legal age for alcohol consumption in NYS), a minor is recruited by the NYPD to make the purchase. After the sale at the storefront, the undercover officer returns to the supervisor, provides the evidence (an audio or video recording if available), and describes the person who sold the evidence to the undercover officer. The supervisor instructs the apprehension team to enter the storefront and confront the suspect. The undercover officer indicates that the apprehension team has the correct individual, and the team either issues a summons or makes an arrest, as appropriate (see NYPD Patrol Guide 214-01 "Padlock Law" Program). After a few of these operations in conjunction with a nuisance abatement proceeding, storefronts quickly stop engaging in these activities. ${ }^{3}$

Eric Garner was the subject of a QOL action originally designed for storefronts. The enforcement action against Eric Garner for selling untaxed cigarettes in an open-air market was initiated by 311 complaints $^{4}$ and QOL complaints. Most such complaints come from legitimate storefront owners who lose business to illicit street sellers. The 311 complaints are monitored by different management levels of the NYPD Patrol Bureau and the Chief of Department. The Chief of Department presents specific QOL issues during the weekly Compstat meetings. Eric Garner's activity was specifically brought up at a Compstat meeting, and the 120th Precinct Commander was directed to address the issue (Daly, 2014). If the Chief of Department specifically indicates a QOL condition, it is expected that the commander will address it immediately.

Eric Garner sold untaxed cigarettes to an undercover police officer in violation of NYS Tax Law 1814. Although the crime is an unclassified misdemeanor and although it is debatable whether the NYPD should be involved in such enforcement, the law made Eric

\footnotetext{
2 Nuisance abatement incidents are considered to be selling marijuana, selling alcohol to minors, selling drug paraphernalia, and selling untaxed and loose cigarettes.

3 The author was in the second NYPD pilot precinct to initiate this program in Spanish Harlem as the conditions sergeant.

${ }^{4}$ New York City has a 311 system for citizens to call for any type of city service. This system is also the preferred way to call the NYPD for police-related requests that do not pertain to an emergency or a crime in progress requiring an immediate response.
} 
Garner subject to an enforcement action. Criminal court summonses are issued for most misdemeanors outside the Penal Law of New York. Misdemeanors in New York that carry a penalty for a previous conviction for the same offense are not eligible for criminal court summonses. To establish a previous conviction for the same offense, the fingerprints of the offender obtained from the current offense are verified against the fingerprints obtained from the previous conviction. Thus, all misdemeanors and violations that raise an offense to a felony upon previous conviction must be fingerprinted. To be fingerprinted, an arrestee must be removed to a facility capable of capturing fingerprints. This necessitates the removal of a suspect to a station house.

The NYPD policy for violation of NYS Tax Law 1814 is to remove the suspect to the station house to be processed and fingerprinted. Although an arrestee may have previous convictions for the same offense, the crime is considered a misdemeanor at the time of arrest. The arrestee may be eligible for a Desk Appearance Ticket (DAT), and the court resolves the felony status of the offense at a later hearing. If eligible for a DAT, the arrestee is released from the station house. If the arrestee does not qualify for a DAT, the arrestee is processed and brought before arraignment in the county of arrest (see NYPD Patrol Guide 208-03 Arrests - General Processing and 208-27 Desk Appearance Ticket General Procedures).

The arrest of Eric Garner was not a summary arrest initiated by an individual police officer, but a coordinated effort to enforce laws against QOL violations. Similar operations involving Eric Garner occurred without incident. On July 17, 2014, Eric Garner decided not to submit to arrest willingly after requests by several police officers. The police officers used physical force to handcuff Eric Garner and place him under arrest. During the brief struggle, police officers brought Eric Garner to the ground and handcuffed him. While resisting the attempts to handcuff him, Eric Garner said "I can't breathe!" 13 times (Goodman \& Baker, 2014). Also during the struggle, Police Officer Pantaleo placed his arm in the neck area of Eric Garner.

The placement of the arm, which lasted for less than 10 seconds, was deemed unacceptable to most observers and was the major focus of attention by critics. Actions by the rest of the officers did not receive as much scrutiny as this one. The uniformed Police Sergeant who was on the scene and appeared not to take any significant supervisory action eventually received department charges. While the EMTs had the primary responsibility for medical assistance, the police officers were responsible for reasonable medical assistance up to the moment the EMTs arrived. There seemed to be a lack of enthusiasm or urgency until this point. As well, the EMTs also seemed unenthusiastic after their arrival, doing the bare minimum. Except for the further appearance of a tepid medical response by the police officers, apart from the slow response of the EMTs, no other officers were subjected to inquiry for their actions.

After being handcuffed, Eric Garner was rolled onto his side to promote free breathing, per NYPD policy. EMTs from Richmond University Medical Center arrived and quickly checked for breathing, a radial pulse, and a carotid pulse per FDNY guidelines. The actions of the EMTs in the video indicate that they had determined that Eric Garner was breathing, had an adequate pulse in his wrist and neck, and was stable for transport. The police officers and the EMTs placed Eric Garner on a gurney and removed him to Richmond 
University Medical Center. Eric Garner arrived at the hospital and was pronounced dead there 1 hour later (Queally, 2015).

The New York Daily News obtained a video recording of the arrest and published it on its website, sparking outrage and criticism of the NYPD. A bystander named Ramsey Orta recorded the video, and Orta claimed that Eric Garner had done nothing wrong and had just broken up a fight. Without further information at the time of the video release, reactions to the video prompted protests. Officer Pantaleo's firearms were removed, and he was assigned to administrative duties. The two EMTs were suspended from answering medical calls under the Fire Department of the City of New York (FDNY)/EMS dispatch service because an FDNY review of the incident erroneously stated that the EMTs had not followed FDNY procedure (NBC New York, 2014, July 17).

An autopsy of Eric Garner conducted by the Office of the Chief Medical Examiner of the City of New York (OCME) determined the manner of death to be a homicide with no direct reference to the cause of death. The autopsy did not reveal any damage to the windpipe or neck bones, a finding that would have been consistent with strangulation or indicative of "choking" (Celona \& Boniello, 2014). Statements released by the Medical Examiner implied that restraint to the neck was the aggravating factor in a person who was obese and who had asthma and heart disease, but it did not provide details about how the Medical Examiner had reached such conclusions (Goldstein \& Santora, 2014). Generally, the OCME provides the manner of death and specific details of the cause of death in public statements.

There is a public perception that all homicides are murders and that if a Medical Examiner determines the manner of death to be a homicide, a murder or manslaughter charge must follow. Although a Medical Examiner may classify the manner of death as a homicide, this does not mean there is criminality. Homicide simply means death caused by another human being, as opposed to suicide or death due to accidental or natural causes. Prosecutors determine criminality. The Richmond County District Attorney's Office conducted a criminal investigation into the death of Eric Garner and presented evidence to a Grand Jury, including the complete autopsy report and testimony of witnesses. Police Officer Pantaleo testified before the Grand Jury for 2 hours (NBC New York, 2014, November 21).

After District Attorney Daniel Donovan presented the case to a Richmond County Grand Jury from September 29 through December 3, 2014, he could not secure a true bill - that is, a majority of the members of the Grand Jury did not find objective facts that would warrant a felony indictment (NBC New York, 2014, November 21). In NYS, Grand Jury records are sealed to prevent the compromise of witnesses and to protect the accused in cases in which no indictment is made. In addition, all evidence, including the autopsy report, is sealed (Queally, 2015). Although the sealing of information given to the Grand Jury is regulated by state law, the lack of transparency contributed to the perception of an inadequate presentation of evidence by the Richmond County District Attorney's office. Because it is not possible for outsiders to review the Grand Jury presentation made by the Richmond County District Attorney, there is no way to determine if the Richmond County District Attorney made a strong case or introduced all relevant evidence to the Grand Jury. The lack of an indictment was perceived as a lack of procedural justice and was met with 
Journal of Criminal Justice and Law:

criticism and protests (Goodman \& Baker, 2014). At this point, all NYS remedies for criminal sanctions were exhausted. ${ }^{5}$

On the same day, December 3, 2014, U.S. Attorney General Eric Holder announced that the U.S. Attorney's Office would conduct its own investigation into the death of Eric Garner (Danna, 2014). Staten Island falls under the jurisdiction of the Eastern District of New York, which was under the control of Loretta Lynch at the time, before she became the U.S. Attorney General. Federal prosecutors generally charge police officers for the excessive use of force under 18 USC § 242 - Deprivation of Rights Under Color of Law. To bring charges, the federal government would be required to show that Officer Pantaleo had deprived Eric Garner of his rights under the Constitution or federal law "... on account of such person being an alien, or by reason of his color, or race." For this claim to be made successfully, it would have to be shown that Officer Pantaleo willfully initiated the encounter on the basis of Eric Garner's race under the guise of a state action.

The government would have several problems bringing a federal charge. Officer Pantaleo did not initiate the encounter. The enforcement action against Eric Garner for selling untaxed cigarettes was initiated because of 311 complaints, QOL complaints, and instructions given to the 120th Precinct Commander at Compstat sessions. Also, there was no guise of a state action. Eric Garner sold untaxed cigarettes to an undercover police officer in violation of NYS Tax Law 1814. Although the crime is an unclassified misdemeanor and it can be debated whether the NYPD should be involved in such enforcement, it did subject Eric Garner to arrest. Therefore, Officer Pantaleo and the other officers at the scene neither initiated the action nor used an enforcement action as a guise for discrimination.

The Eastern District of New York under U.S. Attorney General Loretta Lynch declined to proceed with any action at the time of Eric Garner's death despite objections by the U.S. Department of Justice Civil Rights Division in Washington. Furthermore, the case was not pursued after Loretta Lynch became the U.S. Attorney General (Apuzzo, 2018). Although technically the statute of limitations has not been exceeded, it is unlikely that the current U.S. Attorney General will pursue any action against Officer Pantaleo, having observed no action on the part of his predecessors Loretta Lynch and Eric Holder.

Without the possibility of criminal prosecution, Officer Pantaleo will be tried by the NYPD. The NYPD is bound by case law and therefore could not have started administrative investigations earlier. The NYPD did not take statements from the subject officers to proceed. Under a decision made by the U.S. Supreme Court in Garrity vs. New Jersey (1967), although police administrators and supervisors can compel police officers to testify against their penal interest and Fourth Amendment protections during administrative investigations, these statements may not be introduced in criminal proceedings. Under the

${ }^{5}$ Despite public perception, the NYS Attorney General has limited criminal prosecution power under NYS Executive Law 63 and only that specifically authorized by the governor. The shooting or death of a person in custody in which police are involved generally does not fall within these guidelines. In response to several deaths in police custody, Governor Cuomo has signed an executive order authorizing the NYS Attorney General to investigate deaths in police custody and prosecute when appropriate. Still, although it is legally possible to present a case to a new and different Grand Jury in New York, the reasons to do so must be extremely compelling, or new evidence must have been discovered. 
"fruit of the poisonous tree" doctrine (Nardone $v$. United States, 1939), any future evidence related to the testimony of the subject officers would also be inadmissible.

Although it is technically true that the NYPD could have started an administrative investigation immediately, in practice, this rarely happens without the consent of the involved prosecutors. Most prosecutors fear that such statements, if taken, will be difficult to separate from future statements and the evidence collection needed for a criminal trial. In addition, the statements may be leaked and prejudice a potential jury pool, directly decreasing the likelihood of a successful prosecution. In practice, the NYPD, or any other law enforcement agency, will seek consent from the involved prosecutors before questioning the subjects of an administrative investigation that is likely to lead to criminal charges. In a case such as that of Officer Pantaleo, the consent of the Richmond County District Attorney and the U.S. Attorney for the Eastern District of New York would typically be obtained before the NYPD moved forward.

After the exhaustion of state criminal actions and U.S. civil rights prosecutions, Officer Daniel Pantaleo will be tried in the NYPD trial room under use of force guidelines and other miscellaneous administrative charges. At some point, Officer Pantaleo will be notified by his roll call administrator to report to the Department Advocate. Officer Pantaleo will arrive at One Police Plaza and report to the fourth floor. He will briefly meet with an attorney from the Patrolmen's Benevolent Association (PBA) and then be directed to sign for his Charges and Specifications. The Charge is simply the Patrol Guide rule that allegedly was broken; the Specification is a brief statement describing the conduct that was in violation of the rule. This would be similar to a prosecutor's information, which lists the specific violation of the law, and the "to wit" statement, which briefly describes the action. Officer Pantaleo will be questioned by investigators from the Civilian Complaint Review Board (CCRB), the NYPD Internal Affairs Bureau, or both. Officer Pantaleo will be compelled to answer questions. Failure to answer questions related to the investigation will result in his termination from employment.

Although only a single incident occurred and only one action is in question, the Charges and Specifications will be exhaustive and comprise at least five specifications related to the one action. Officer Pantaleo will be charged with specifications that include inappropriate use of force, unauthorized restraining techniques, use of a chokehold, and administrative charges such as incomplete activity log entries. To be more specific, the top charge most likely will be violation of Patrol Guide 221-01 Force Guidelines rule number 2 subdivision a, which reads as follows: "2. Members of the service SHALL NOT: a. Use a chokehold." As defined earlier in the Patrol Guide, "A chokehold shall include, but is not limited to, any pressure to the throat or windpipe, which may prevent or hinder breathing or reduce intake of air." The second charge will likely be Patrol Guide 221-02 Use of Force rule number 11, which instructs officers to "apply no more than the reasonable force necessary to gain control." Additional charges will be related to the use of force procedures. The last charge listed against him will likely be "engaging in conduct prejudicial to good order, efficiency, or discipline of the Department." This rule is embedded in Patrol Guide 203-10 Public Contact - Prohibited Conduct. The last charge is not clearly defined and is 
Journal of Criminal Justice and Law:

meant to be ambiguous. It is basically a catch-all similar to disorderly conduct or disturbing the peace. ${ }^{6}$

Officer Pantaleo will leave the office of the Department Advocate after briefly talking to his PBA attorney. The PBA attorney may already have prepared a pre-negotiated plea bargain consisting of loss of vacation days and extended disciplinary probation, but this is unlikely. Officer Pantaleo will either be offered a punishment so excessive that he will not accept it, simply be told he will be going to trial, or be asked to resign with a stipulation of loss of accrued time, loss of pension, or a monetary fine.

A department trial is similar to a military tribunal except that there is only one judge, with the title of Trial Commissioner. Unlike in a special military court martial for cases involving fatalities, in which there is the premise that the three senior commissioned officers sitting on the tribunal have had direct combat experience, a Trial Commissioner does not have any direct field law enforcement experience. The prosecutors from the CCRB will make a case against Officer Pantaleo, and his union attorney will make counterarguments. Despite a semblance of procedure and the use of rules of evidence, some of the rules are relaxed compared with the rules of evidence in a typical criminal or civil trial in New York.

Although the NYPD has exhaustive procedures for preparing and serving Charges and Specifications, no published procedures or guidelines for a department hearing exist. Witnesses will be brought in to testify, a video will be shown, and Officer Pantaleo's past discipline and training records will be introduced. As to what constitutes the standard of proof to prevail in a case, no one can entirely agree. From experience, it is somewhere between preponderance of the evidence and clear and convincing evidence (both rather loosely understood) and can vary from trial to trial and from Trial Commissioner to Trial Commissioner.

The Trial Commissioner will have to determine if Officer Pantaleo acted within department guidelines, whether a chokehold was applied, and whether the chokehold was intentional or inadvertent. If the Trial Commissioner fairly looks at the training methods given to Officer Pantaleo, the Trial Commissioner will have to determine if Officer Pantaleo acted in a manner consistent with department training and if the training methods led to Officer Pantaleo's placing his arm in the area of Eric Garner's neck and shoulder.

From an outside point of view, it would appear that Officer Pantaleo violated department guidelines by engaging in a prohibited act. Unfortunately, the use of force procedures in the NYPD Patrol Guide are proscriptions - that is, the manual dictates what a police officer should not do. In fact, most of the use of force procedures are written as prohibitions. Little is stated about how a police officer should use force. Use of force is prescribed through training. Use of force methods are taught during the initial police academy training, plain clothes training, and, to a limited extent, in-service training. Police recruits are trained on one-man takedowns, two-man takedowns, and the "seat belt" takedown. Additionally, when a police officer is assigned to a plain clothes unit in the NYPD, the police officer must report to tactical training before assignment and be trained on variations of these techniques again.

${ }^{6}$ Editor's note: Officer Pantaleo's departmental trial has been set to begin on May 13, 2019 (Morales, 2018). 
The two-man takedown and the "seat belt" takedown involve placing the arm across the subject's chest and one shoulder to bring the subject to the ground. The concept is that a forward motion above a person's center of gravity will bring the person to the ground and remove the person's stable base to fight back. While the individual is on the ground, the officers can handcuff the individual. Once the individual is handcuffed, the police officers are instructed to place the person on one side to promote free breathing. The preference is to place the person on the left side to facilitate blood flow from the heart. On any given day throughout the nation, police officers successfully use these techniques to control those who resist arrest, with no fatal outcomes. There is no guidance on what to do if the arm accidentally slides up to the neck region, nor are police officers trained on persons other than police academy instructors who are in peak physical condition and whose body types vary little. Officer Pantaleo was trained in these techniques at least twice, first during his academy training and again before he was assigned to a plain clothes unit.

Certainly, asphyxia, the condition in which the deprivation of oxygen leads to unconsciousness or death, was such a concern to the NYPD that they banned chokeholds involving nightsticks in the late 1980s. Before this prohibition, NYPD officers were trained on how to place and use their nightstick against one of the carotid arteries in the neck to force arrestees into submission. There was a concern that once partially denied of oxygenated blood, a person would never recover from such oxygen loss and would die. This false concept was reinforced in a study conducted by Reay et al. (1988), which showed the effects of position on the oxygen saturation of subjects who were hog-tied. In hog-tying, a person's hands are restrained behind the back (usually with handcuffs), the ankles are restrained with either rope or ties, and the ankle restraint is then connected to the restrained hands. As a result of this study and other factors, the NYPD banned chokeholds with nightsticks and hog-tying.

Asphyxia is a serious concern to law enforcement officers as both a form of attack and means of submission. Physiologists and medical doctors have proved that blood oxygen levels recover quickly after physical asphyxia. In other words, if a chokehold is applied and then removed, the subject will recover and not continue into a death spiral due to the initial lack of oxygen. In fact, the U.S. District Court of Appeals for the Ninth Circuit, arguably the most liberal circuit in the United States, determined in Price v. County of San Diego (1998) that hog-tying was not a contributing factor in the death of Daniel Price. The court heavily relied on a study by Dr. Tom Neuman about an experiment he and others had conducted in an attempt to duplicate the findings of Dr. Reay. Dr. Neuman could not replicate Dr. Reay's results and in direct contrast found that hog-tying did not cause clinically relevant changes in oxygenation or ventilation (Chan, Vilke, Neuman, \& Claussen, 1997). In the decision, the court completely rejected Dr. Reay's finding, determining that "the UCSD study, which Dr. Reay concedes rests on exemplary methodology, eviscerates Dr. Reay's conclusions." (Price v. County of San Diego, 1998, p. 14). Although the NYPD prohibition of chokeholds is still an admirable policy, it relied on poor science.

If the Trial Commissioner has field experience, he or she may understand that even with the best of training, mishaps occur during field operations. Given the current political pressure, the most likely outcome for Police Officer Pantaleo is termination. The large, multimillion-dollar settlement that was pre-negotiated, not awarded, to the Garner family by Mayor de Blasio makes it unlikely that any of his appointees will allow any other 
outcome, including the NYPD Trial Commissioners and the CCRB prosecutors. Police Commissioner O'Neill has one layer of separation from the CCRB trial of Officer Pantaleo, but he will nonetheless experience the wrath from any outcome of this administrative trial because he must personally approve the penalty.

If Officer Pantaleo is found guilty, he may request an Article 78 motion to have the entire procedure reviewed by the NYS Supreme Court (which is a trial level court in the NYS judicial system), so that the entire transcript and evidence rules of this particular hearing will be exposed. Review of the case by the court could have a favorable outcome. The NYS Supreme Court would review introduced evidence under the generally accepted practice of Civil Practice Laws and Rules, without being subjected to the political pressure imposed on the Trial Commissioner. It is possible that the decision could be reversed at a state hearing, forcing the City of New York to make another settlement involving this incident.

The exhaustive demonstration of the disciplinary process of the NYPD for just this one police officer is in stark contrast to the effort to review policies continually. Had the NYPD put one-fifth of the effort that will be expended in disciplining Police Officer Pantaleo into policy review, perhaps it would have been determined that existing policies such as the Padlock Program are outdated. The policy simply outlived its useful purpose and was allowed to creep into different enforcement facets where it was never originally intended to be applied. A simple review would have at least discovered the mission creep. A comprehensive review involving a basic cost-benefit analysis would have determined that the Padlock Program has the potential to be abused by actors unaware of the downstream effects.

No matter the outcome of the Pantaleo administrative trial, the conviction of this solitary police officer will have little effect on the operational considerations of the NYPD. The city administration will be proud to demonstrate how harsh it is when police officers violate department rules. Advocates for Eric Garner will view city administrators as inept because they could not get a criminal conviction. The PBA will advise its officers not to perform selfinitiated actions, to take less risk in their law enforcement actions, and await direct supervision for any arrest that may result in conflict. In short, everybody loses. Instead of trying the police officer, an examination of NYPD policy would be more productive and appropriate.

After an explanation of some of the nuances of the Eric Garner incident, one must ask several questions. How did an enforcement action based on a policy designed to close down illicit storefronts causing nuisances in communities in the mid-1990s lead to the death of a man in 2014? How do a police agency and a district attorney's office show greater transparency in the criminal investigation of a person killed by the police? What can be done to prevent the future injury and death of people taken into custody? The author suggests the following changes in policy and legislation.

\section{Re-Examine Civil Enforcement Programs to Determine if They Should Continue}

The inception of the nuisance abatement program in the mid-1990s had a noble goal of removing stores acting as fronts for illegal activities; it was not designed or intended to prevent loose cigarette sales in streets, on sidewalks, or in park areas. The program was 
successful and accomplished its mission quickly. Instead of re-evaluating the usefulness and effectiveness of the program, the NYPD allow mission creep to occur, and the program expanded into residential locations and public spaces. This expansion should be reexamined. Is it appropriate to execute a nuisance abatement procedure on an apartment rented by the grandmother of a drug dealer 6 months after the fact (Baker, 2016)?

The NYPD, or any law enforcement agency with nuisance abatement programs, should re-examine its current policies and determine how they can be implemented immediately without a need for the consent of a legislative body. The analysis should focus on the original purpose for the program, whether it has accomplished its original goal, and whether it should be continued or reapplied to other, similar conditions in a controlled manner. Because these steps are within complete control of the agency, they can be implemented immediately.

\section{Allow Grand Jury Transcripts to be Released When a Person Dies While in Police Custody}

The sealing of Grand Jury records for unindicted cases is guided by NYS Criminal Procedure Law 190.85 and other applicable laws. The legal reasoning, among other concerns, was to protect witnesses from retaliation in cases that did not go forward and to prevent harm to the accused (People v. DiNapoli, 1970, p. 235). The legislation should be changed to allow the release of Grand Jury transcripts and evidence in cases involving deaths in police custody because the logic of the legal reasoning is not generally applicable to accused police officers.

The argument that sealing Grand Jury transcripts from the public will prevent accused officers from learning the identities of witnesses testifying against them in a Grand Jury proceeding is frail. This is not to suggest that rogue police officers would not attempt to retaliate against witnesses. Subject police officers could learn the identity of witnesses testifying against them through means other than Grand Jury transcripts. In most cases, the subject officers were directly involved in the incident and collected the preliminary information, including witness names, for the investigation. In addition, it is less likely that a subject police officer would retaliate against a witness as a consequence of the increased scrutiny of an internal investigation and the lack of a reaction because of the lack of an indictment.

Changing state law requires action of the state legislature with approval of the executive branch, in most cases. In New York, this would require the introduction of a bill by the Assembly or Senate, approval by both houses, and a signature by the governor. A proposed bill could be introduced and enacted within one legislative session, or approximately one year in most states.

\section{Examine the Possibility of Using Takedown Techniques That Preferably Avoid Neck Placement}

Agencies should explore realistic techniques that will reduce injuries to both arrestees and police officers. These techniques should be simple, teachable, and retainable, and it should be possible to replicate them for large training groups. Although martial art techniques may be effective, the moves can be complex and rely on consistent retraining, practice, and 
mental memory. However, most agencies do not have the luxury of providing such training time in consideration of their operational needs (Williams, 2000). The NYPD has attempted to adopt techniques that avoid the neck but has fallen into the trap of attempting to train officers in the use of a Jujitsu arm bar hammerlock technique during a short session on the last day of a 3-day training course (Weiss, 2015), with no planned follow-up training to maintain proficiency. Techniques that do not require advanced placement skills and involve no more than three moves, in addition to basic skills such as pulling, pushing, twisting, and bending, should be considered. The development of motor memory techniques to avoid the neck may assist in reducing the number of deaths (Flosi, 2011). Although most agencies have the resources to develop physical training, the development of such techniques will most likely need some outside guidance.

Mechanical force options such as oleoresin capsicum (OC) spray and conductive electronic devices (CEDs) should be considered, and their use in taking down resistant arrestees is strongly encouraged. Although not $100 \%$ effective, OC spray may provide a means to enforce compliance with a minimum of effort and is an alternative that is available to most police officers in their utility belt. OC spray has been in use since the 1990s (Morabito \& Doerner, 1997) and is available to all NYPD officers in the field.

The NYPD experience with CEDs prompted the creation of policies that restricted their use to supervisors and specialty personnel. Ironically, the policy to restrict the use of CEDs by police officers in the NYPD was prompted by abuse by a police supervisor. Specifically, after Sergeant Pike in 1985 used a stun gun on a teenage male suspect (Raab, 1985), CED use was restricted to supervisors and members of the NYPD Emergency Service Unit. To reduce the number of physical takedowns, CEDs should be issued to police officers in the field, not kept in reserve for police supervisors and emergency service personnel, who will likely arrive at an arrest scene too late to use them effectively.

The tragic death of Eric Garner exposed policy and training issues. Convicting a police officer of administrative charges to produce some type of closure is politically expedient, but it does not solve the problem at hand. A close review of enforcement strategies such as QOL and civil enforcement methods must be undertaken immediately. Criminal proceedings involving police officers need to be more transparent. Takedown techniques that can reduce exposure to the neck area must be explored. These changes in policy would be the most productive tribute to the legacy of Eric Garner.

\section{Declaration of Conflicting Interests}

The author declares no potential conflicts of interest with respect to the research, authorship, and/or publication of this article.

\section{Funding}

The author received no financial support with respect to the research, authorship, and/or publication of this article.

\section{References}

Apuzzo, M. (2018, April 20). Charges sought in Eric Garner's death, but justice officials have doubts. The New York Times, p. A1.

Associated Press. (2016, February 23). Hospital that treated Eric Garner to pay family \$1M. The New York Post. 
Baker, A. (2016, February 11). City to review nuisance law that has led to evictions. The New York Times, p. A28.

Baker, A., Goodman, J., \& Meuller, B. (2015, June 14). Beyond the chokehold. The New York Times, p. A1.

Celona, L., \& Boniello, K. (2014, July 19). Man in chokehold death had no throat damage: autopsy. The New York Post.

Chan, L., Vilke, G., Neuman, T., \& Claussen, J. (1997). Restraint position and positional asphyxia. Annals of Emergency Medicine, 30(5), 578-586.

Daly, M. (2014, December 5). Eric Garner was just a number to them. Daily Beast.

Danna, E. (2014, December 3). Attorney General Eric Holder announces justice department civil rights investigation in Eric Garner death. SILive.

Flosi, E. (2011). Sudden in-custody deaths: Exploring causality \& prevention strategies. Forensic Examiner, 20(1), 31-48.

Goldstein, J., \& Santora, M. (2014, August 2). Staten Island man died from chokehold during arrest. The New York Times, p. A14.

Goldstein, J., \& Schweber, N. (2014, July 19). Staten Island man died from chokehold during arrest, autopsy finds. The New York Times, p. A1.

Goodman, D., \& Baker, A. (2014, December 4). New York officer facing no charges in chokehold case. The New York Times, p. A1.

Morabito, E., \& Doerner, W. (1997). Police use of less-than-lethal force: Oleoresin Capsicum (OC) spray. Policing, 20(4), 680-672.

Morales, M. (2018, December 6). Four years after Eric Garner's death, officer faces NYPD trial to see if he will keep his job. CNN.

Murray, K., Marcius, C., \& Parascandola, R. (2014, July 18). Staten Island man dies after NYPD cop puts him in chokehold - see the video. Daily News.

NBC New York. (2014, July 17). EMS on modified duty, cop stripped of badge in chokehold arrest death.

NBC New York. (2014, November 21). NYPD officer testifies about Eric Garner chokehold death.

Queally, J. (2015, March 19). In Eric Garner case, judge denies request to release grand jury transcripts. Los Angeles Times.

Raab, S. (1985, April 23). Police sergeant and officer are charged with torturing youth after arrest. The New York Times, p. B1.

Reay, D., Howard, J., Fligner, C., \& Ward, R. (1988). Effects of positional restraint on oxygen saturation and heart rate following exercise. American Journal of Forensic Medicine and Pathology, 9(1), 16-18.

Weiss, M. (March 2, 2015). NYPD trains officers on new takedown methods that avoid chokeholds. On the Inside.

Williams, G. (2000). Moving from martial arts to principle-based training. Law \& Order, 48(6), 115-118.

\section{Cases Cited}

Garrity v. New Jersey, 385 U.S. 493 (1967).

Nardone v. United States, 308 U.S. 338 (1939).

People v. DiNapoli, 27 N.Y.2d 229 (N.Y. Ct. App. 1970). 
Journal of Criminal Justice and Law:

Price v. County of San Diego, 990 F. Supp. 1230 (S.D. California 1998).

\section{Author Biography}

Andrew J. Costello has been an Assistant Professor of Criminal Justice at the New York Institute of Technology since 2016 after retiring from a 26-year career with the New York City Police Department (NYPD). He received his doctorate from John Jay College in 2013 while working full time for the NYPD. Andrew Costello has worked in the Patrol, Transit, and Detective Bureaus of the NYPD in addition to working for the Police Commissioner's Office of Analysis, Management, and Planning (OMAP). In addition performing enforcement duties, he has analyzed and drafted agency-wide policies for the NYPD while assigned as an analyst in OMAP, in addition to policies directly related to investigations for the Detective Bureau. 